\title{
Inhibitory quotient in HIV pharmacology
}

\author{
Charles la Porte \\ From $16^{\text {th }}$ International Symposium on HIV and Emerging Infectious Diseases \\ Marseille, France. 24-26 March 2010
}

\section{Aim}

This presentation will review the concept of the inhibitory quotient and its use in HIV pharmacology.

\section{Materials and methods}

Recent publications including research articles, abstracts and review articles were retrieved to provide an overview of recent advances in the field.

\section{Results}

The inhibitory quotient is the ratio of drug exposure to viral susceptibility. There are a number of different ways to calculate the inhibitory quotient. The trough concentration is the most frequently used pharmacokinetic parameter to represent drug exposure in inhibitory quotient calculations. To represent resistance, both phenotypic and genotypic data can be used to calculate the inhibitory quotient. Using population averages for drug exposure and resistance it is possible to compare the inhibitory quotient of different drugs. More frequently the inhibitory quotient is used in the context of therapeutic drug monitoring. The inhibitory quotient has mainly been studied for protease inhibitors. For nonnucleoside reverse transcriptase inhibitors a single mutation can cause high level resistance, whereas for PIs, mutations have a smaller but cumulative effect. For this reason it is unlikely that the inhibitory quotient will be helpful in the therapeutic drug monitoring of nonnucleoside reverse transcriptase inhibitors. For the newer drugs in the classes of CCR5 and integrase inhibitors it is not yet clear what the role for inhibitory quotient could be. In terms of therapeutic drug monitoring cutoff values have been proposed for the genotypic inhibitory quotient as well as for the phenotypic inhibitory quotient.

Ottawa Hospital Research Institute and University of Ottawa, Ottawa, Canada

\section{Discussion}

The inhibitory quotient has been topic of discussion for the past decade. We have moved from the initial discussions on how to compare inhibitory quotients for different drugs into the use of inhibitory quotient as a useful parameter for therapeutic drug monitoring. Further data are needed to confirm the respective roles of different forms of inhibitory quotient in daily practice.

Published: 11 May 2010

doi:10.1186/1742-4690-7-S1-19

Cite this article as: la Porte: Inhibitory quotient in HIV pharmacology.

Retrovirology 2010 7(Suppl 1):19.
Submit your next manuscript to BioMed Central and take full advantage of:

- Convenient online submission

- Thorough peer review

- No space constraints or color figure charges

- Immediate publication on acceptance

- Inclusion in PubMed, CAS, Scopus and Google Scholar

- Research which is freely available for redistribution

Submit your manuscript at www.biomedcentral.com/submit
C Biomed Central 